\title{
PERANCANGAN SISTEM INFORMASI PEMINJAMAN DAN PENGEMBALIAN BUKU PERPUSTAKAAN PADA SMA MUHAMMADIYAH 1 BANDAR SRIBHAWONO BERBASIS WEB MENGGUNAKAN METODE RAPID APPLICATION DEVELOPMENT (RAD)
}

\author{
Yuan Levai Leo ${ }^{1)}$, Sudarmaji ${ }^{2)}$, Dedi Irawan ${ }^{3)}$ \\ Program Studi IImu Komputer, Fakultas IImu Komputer, \\ Universitas Muhammadiyah Metro \\ Jl.Gatot Subroto No.100 Yosodadi Kota Metro
}

\begin{abstract}
Abstrak - Pengelolaan proses peminjaman dan pengembalian buku perpustakaan dapat memakan banyak waktu karena perlu pencatatan oleh petugas yang harus dilakukan secara manual. Pemanfaatan sistem informasi peminjaman dan pengembalian perpustakaan berbasis web dapat menghemat waktu dan tenaga. karena proses sudah dilakukan menggunakan komputer. Penelitian ini bertujuan untuk: membuat sistem informasi perpustakaan berbasis web di SMA Muhammadiyah 1 Bandar Sribhawono, yang diharapkan dapat mempermudah petugas perpustakaan dalam pengolahan data transaksi yang terjadi seperti peminjaman, pengembalian, stok buku dan pencarian buku, serta dalam pembuatan laporan - laporan. Model proses pengembangan software digunakan model RAD (Rapid Application Development). Yaitu: Requirements/perencanaan, Workshop Design, dan implementasi. Kemudian digunakan pemodelan visual UML yaitu standarisasi bahasa pemodelan untuk pembangunan perangkat lunak berorientasi objek. Hasil penelitian diketahui bahwa: sistem informasi dikembangkan menggunakan framework Laravel dan model pengembangan RAD.
\end{abstract}

Kata Kunci: Perancangan, Sistem Informasi, Peminjaman, Perpustakaan, Rapid Application Development, Web, Laravel

\begin{abstract}
The management of the process of borrowing and returning library books can take up a lot of time because the recording by the officer must be done manually. The utilization of the information system of borrowing and returning library websites can save you time and effort. because the process has been done using a computer. This study aims to: make a library information system web-based SMA Muhammadiyah 1 Bandar Sribhawono, which is expected to facilitate the library staff in data processing transactions that occurred such as borrowing, repayment, stock books and search of the book, as well as in making the reports. Model of the software development process used RAD (Rapid Application Development). Namely: Requirements/planning, Workshop Design, and implementation. Then used visual modeling, UML, namely the standardization of the modeling language for the construction of object-oriented software. The research result shows that: the information system is developed using the framework Laravel and model development RAD.
\end{abstract}

Keywords: Design, Information Systems, Lending, Library, Rapid Application Development, Website, Laravel

\section{PENDAHULUAN}


SMA Muhammadiyah 1 Bandar Sribhawono merupakan salah satu sekolah swasta yang berada di Desa Srimenanti Kecamatan Bandar Sribhawono Kabupaten Lampung Timur dengan jumlah siswa kelas $X: 31$ orang, kelas XI : 23 dan kelas XII : 27 (Jumlah $=81$ orang).Perpustakaan SMA Muhammadiyah 1 Bandar Sribhawono merupakan Perpustakaan Sekolah yang telah memiliki banyak koleksi buku bacaan maupun buku pelajaran sesuai standar Perpustakaan Sekolah. Setiap siswa-siswi juga sudah memiliki kartu anggota perpustakaan yang dapat digunakan untuk meminjam buku di Perpustakaan. Saat ini sistem yg ada pada Perpustakaan SMA Muhammadiyah 1 Bandar Sribhawono masih menggunakan sistem manual yaitu mencatat pada buku peminjaman dan pengembalian. Disamping itu ketika ada penambahan buku baru penjaga perpustakaan hanya mencatat data buku masuk dan langsung menyimpannya di rak yang sesuai dalam kategori buku, sehingga belum adanya pendataan buku secara teratur. Kendala lainya yaitu anggota perpustakaan mengalami kesulitan dalam proses pencarian buku yang akan dipinjam, karena harus mencari langsung pada rak-rak buku. Dalam pembuatan laporan, petugas perpustakaan hanya menyajikan laporan setahun sekali berdasarkan buku catatan peminjaman dan pengembalian. Serta laporan jumlah buku yang masuk tiap tahunnya. Berdasarkan permasalahan pada latar belakang di atas, maka dibuatlah "Sistem Informasi Peminjaman dan Pengembalian Buku Perpustakaan Berbasis web pada Perpustakaan SMA Muhammadiyah 1 Bandar Sribhawono Menggunakan Metode
Rapid Application Development"yang nantinya dapat memberikan kemudahan kepada pengguna dan membuat fitur - fitur untuk memenuhi kebutuhan petugas perpustakaan. Sistem Informasi ini, diharapkan dapat menambah nilai guna terhadap perpustakaan di SMA Muhammadiyah 1 Bandar Sribhawono, terutama bagi petugas perpustakaan dalam pengolahan data transaksi yang terjadi seperti peminjaman, pengembalian, stok buku dan pencarian buku berdasarkan kategori, serta dalam pembuatan laporan - laporan tiap periodiknya.

\section{KAJIAN PUSTAKA DAN LANDASAN TEORI \\ Sistem}

Menurut Azhar yang dikutip oleh Gunardi dan Sugiyanto [1, p. 184], mengatakan bahwa : Sistem adalah kumpulan atau group dari sub sistem/ bagian/ komponen apapun, baik fisik maupun non fisik, yang saling berhubungan satu sama lain, dan bekerja sama secara harmonis untuk mencapai satu tujuan tertentu". Sedangkan Menurut Jogiyanto yang dikutip oleh Mara Destiningrum dkk [2, p. 31],mengatakan bahwa : Sistem adalah suatu jaringan kerja dari prosedur-prosedur yang saling berhubungan, berkumpul bersama-sama untuk melakukan suatu kegiatan atau untuk menyelesaikan suatu sasaran tertentu".

\section{Informasi}

Menurut Jogiyanto yang dikutip oleh Syahrul Mauluddin dan Nakya Santini[3, p. III.12]: "Informasi adalah data yang telah diolah menjadi bentuk yang lebih berarti dan berguna bagi penerimanya untuk mengambil 
keputusan masa kini maupun masa yang akan datang". Sedangkan Menurut Latief Arda yang dikutip oleh Syahrul Mauluddin dan Nakya Santini [3, p. III.12] : Informasi adalah "hasil dari pengolahan data yang digunakan untuk memperbaharui pengetahuan yang telah ada sebelumnya".

\section{Sistem Informasi}

Menurut Nurlaela yg dikutip oleh Asti Herliana [4, p. 43] mengatakan bahwa : Pengertian sistem informasi adalah sistem yang menyediakan informasi dengan cara sedemikian rupa sehingga bermanfaat bagi penerima. Secara lebih detail, sistem informasi dapat didefinisikan sebagai seperangkat entitas yang terdiri dari hardware, software dan brainware yang saling bekerjasama untuk menyediakan data yang diolah sehingga berguna dan bermanfaat bagi penerima data tersebut. Sedangkan menurut Al-bahra Bin Ladjamudin yang dikutip oleh Mara Destiningrum dkk[2, p. 31], mengatakan bahwa : Sistem Informasi adalah: "suatu sistem yang dibuat oleh manusia yang terdiri dari komponen-komponen dalam organisasi untuk mencapai suatu tujuan yaitu menyajikan informasi”.

\section{Perancangan}

Menurut Mohamad Subhan yang dikutip oleh Gunadi dan Sugiyanto [1, p. 184] Mengatakan bahwa : Perancangan adalahprosespengembangan spesifikasi baru berdasarkan rekomendasi hasil analisis sistem.

\section{Perpustakaan Sekolah}

Menurut Bafadal yang dikutip oleh Rahmawati [5, p. 79] mengatakan bahwa: Perpustakaan sekolah merupakan bahan pustaka cetak maupun noncetak yang telah terorganisir secara sistematis dalam suatu ruangan yang digunakan untuk membantu para siswa dan guru dalam menunjang proses pembelajaran di sekolah. Sedangkan menurut Darmono Yang dikutip oleh Rahmawati[5, p. 79]: Perpustakaan sekolah menjadi salah satu bagian penting dalam program sekolah secara keseluruhan, karena perpustakaan sekolah juga turut menentukan keberhasilan proses pendidikan dan pembelajaran bagi para siswanya.

\section{Peminjaman Dan Pengembalian Buku}

Menurut Darwati dikutip oleh Erjon [6, p. 41], mengatakan bahwa : Peminjaman buku yaitu kegiatan yang dilakukan oleh anggota suatu perpustakaan untuk proses peminjaman buku dengan syarat dan ketentuan yang berlaku dalam perpustakaan seperti jumlah buku, judul buku dan lama pinjam.

Menurut Darwati dikutip oleh Erjon [6, p. 41], mengatakan bahwa : Pengembalian buku adalah kegiatan yang dilakukan oleh anggota perpustakaan yang mengacu pada peminjaman buku,Dengan ketentuan jumlah buku, judul buku dan tanggal kembali harus sesuai dan jika tidak sesuai akan diberikan sanksi administrasi.

\section{Web}

Menurut Puspitosari dikutip oleh Ade Suryadi dan Yuli Siti Zulaikah dalam jurnal Khatulistiwa Informatika [7, p. 14], menjelaskan bahwa : "Web adalah halaman informasi yang disediakan melalui jalur internet sehingga bisa diakses di seluruh dunia, selama 
terkoneksi dengan jaringan internet".Sedangkan menurut Puspitosari dikutip oleh Ade Suryadi dan Yuli Siti Zulaikhah [7, p. 14], menjelaskan bahwa "Website adalah halaman informasi yang disediakan melalui jalur internet sehingga bisa diakses di seluruh dunia, selama terkoneksi dengan jaringan internet".

\section{Rapid Application Development (RAD)}

(RAD) Rapid Application Development (RAD) menurut Aswati dikutip oleh [9, p. 8648] "RAD yaitu suatu metode pengembangan sekuensial linier yang menekankan siklus waktu pengembangan dengan singkat dalam pengembangan perangkat lunak. Berikut tahapan dari RAD menurut (Kendall, 2011) :

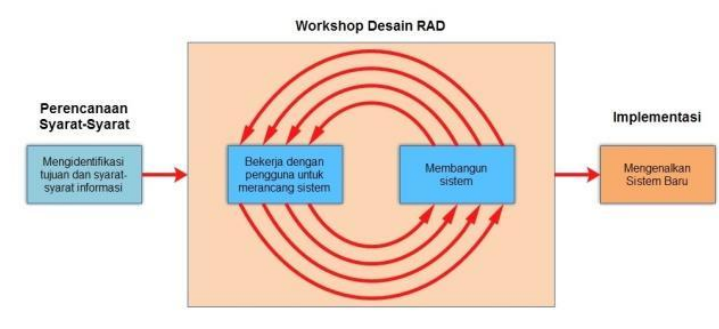

Gambar 1. Tahapan RAD

a. Perencanaan syarat-syarat yang terdiri dari analisis kebutuhan sistem

b. Workshop desain RAD yang merupakan tahapan dimana perancangan melibatkan pengguna,

c. Implementasi yang merupakan tahap sistem telah disepakati, dibangun, serta disempurnakan kemudian dilakukan pengujian dan dikenalkan kepada pengguna.

\section{METODE}

Metodologi terdiri dari metode mengumpulkan data-data yang meliputi studi literatur, observasi, dan wawancara, serta tahapan peneliti yang dilakukan dari proses awal sampai proses akhir.

a. Studi Lapangan

Studi lapangan yaitu pengumpulan data dari perusahaan dengan mencatat data -data dari dokumen perusahaan.

b. Wawancara (Interview)

Dalam penelitian penulis melakukan wawancara atau tanya jawab kepada Ibu Soleha, S.Pd selaku Kepala sekaligus petugas perpustakaan SMA Muhammadiyah 1 Bandar Sribhawono.

c. Pengamatan (Observasi)

Dalam penelitian ini, penulis melakukan Pengamatan secara langsung terhadap kegiatan apa saja yang ada sekolah di SMA Muhammadiyah 1 Bandar Sribhawono pada saat riset penelitian.

d. Dokumentasi (Documentation)

Dokumentasi yaitu mengumpulkan data atau dokumen baik itu berupa tulisan, atau gambar visual (foto) yang ada di sekolah SMA Muhammadiyah 1 bandar Sribhawono.

e. Studi Pustaka

Teori yang diperoleh dengan menggunakan teknik ini adalah mengenai definisi Sistem informasi, Perpustakaan, pemrograman berorientasi objek, MVC, metode RAD (Rapid Application Development), UML(Unified Modeling Language), PHP, MySQL, Framework Laravel, dan definisi lainnya yang berkaitan dengan objek penelitian. 
HASIL DAN PEMBAHASAN

Desain (Workshop Desain RAD)

Desain Flowchart

Pada gambar dibawah ini menjelaskan tentang desain flowchart yang diusulkan, serta proses-proses dan pihak-pihak yang terlibat didalamnya.

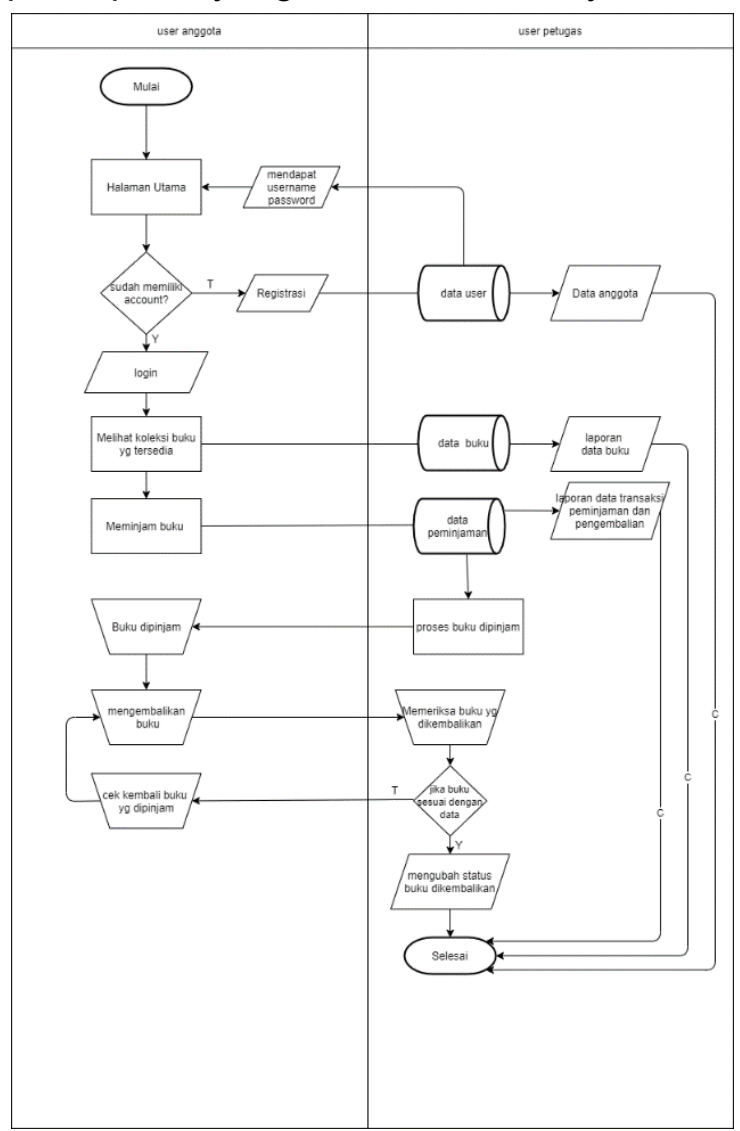

Gambar 2. Desain Flowchart Sistem

\section{Perancangan Unified Modeling \\ Language (UML)}

Desain sistem yang akan

dikembangkan meliputi perancangan Unified Modelling Language (UML),

a. Use Case Diagram Sistem

Use case diagram menggambarkan aktor dan hubungan dengan fungsi-fungsinya masing-masing. Dalam sistem informasi yang dikembangkan terdapat 2 faktor yaitu admin dan siswa.

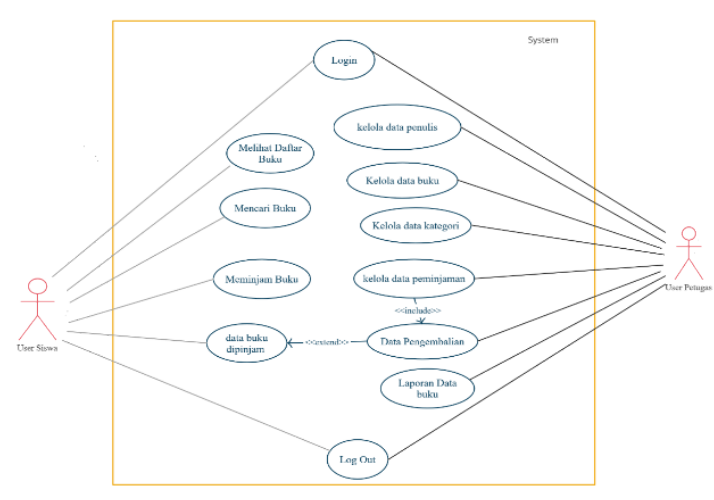

Gambar 3 Use Case Diagram Sistem

b. Use Case Diagram

Admin Admin merupakan aktor yang memiliki hak akses penuh terhadap pengelolaan sistem informasi. Fungsi admin diantaranya adalah pengelolaan terhadap data buku, data penulis, data kategori buku,data user, data peminjaman, dan laporan. Syarat untuk mengakses fungsi tersebut adalah harus melalui fungsi login sebagai admin terlebih dahulu.

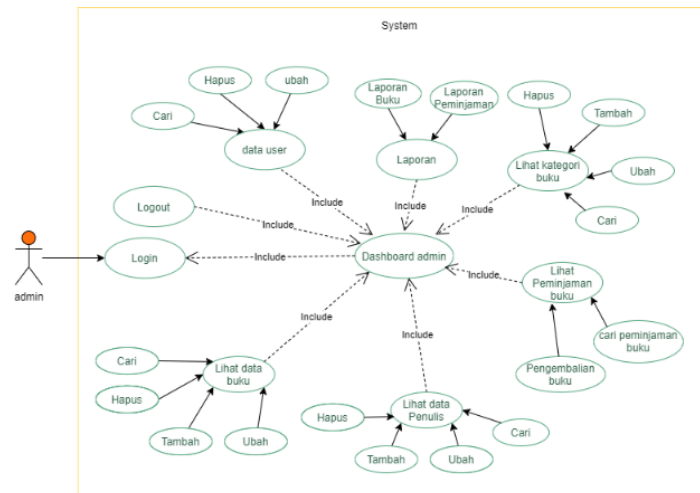

Gambar 4 Usecase Diagram Admin

c. Use Case Diagram User Siswa

Siswa merupakan aktor yang memiliki hak akses terbatas terhadap pengelolaan sistem informasi. Fungsi siswa diantaranya adalah melihat daftar buku yang tersedia, peminjaman buku,melihat buku yg sedang dipinjam dan melihat informasi perpustakaan. Syarat untuk mengakses fungsi tersebut adalah 
harus melalui fungsi login sebagai siswa terlebih dahulu.

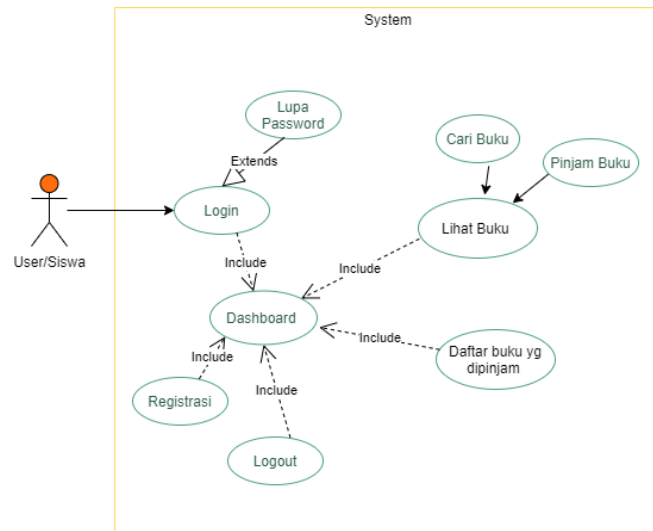

Gambar 5 Usecase Diagram Admin

d. Class Diagram

Diagram tersebut menggambarkan fungsi-fungsi yang ada dalam sistem informasi perpustakaan berbasis framework Laravel. Framework ini menggunakan konsep MVC yang dibangun dari model, view dan controller.

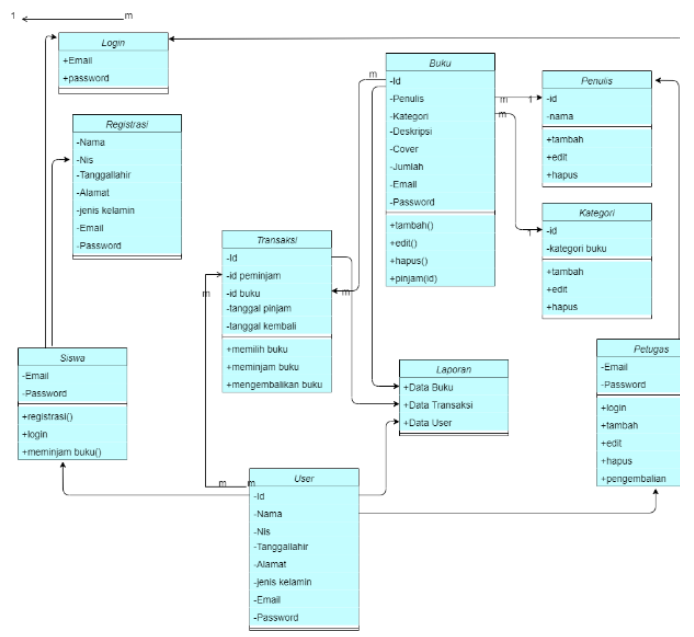

Gambar 6 Class Diagram Sistem

\section{Rancangan Relasi Tabel}

Perancangan database terdiri dari 5 tabel. Tabel users memiliki 12 atribut yang digunakan untuk menyimpan data pengguna yaitu admin dan siswa, tabel borrow history memiliki 7 atribut yang digunakan untuk menyimpan data peminjaman buku, tabel books memiliki
9 atribut yang digunakan untuk menyimpan data buku, tabel authors memiliki 4 atribut yang digunakan untuk menyimpan data penulis buku, serta tabel category memiliki 4 atribut yang digunakan untuk menyimpan data kategori buku.

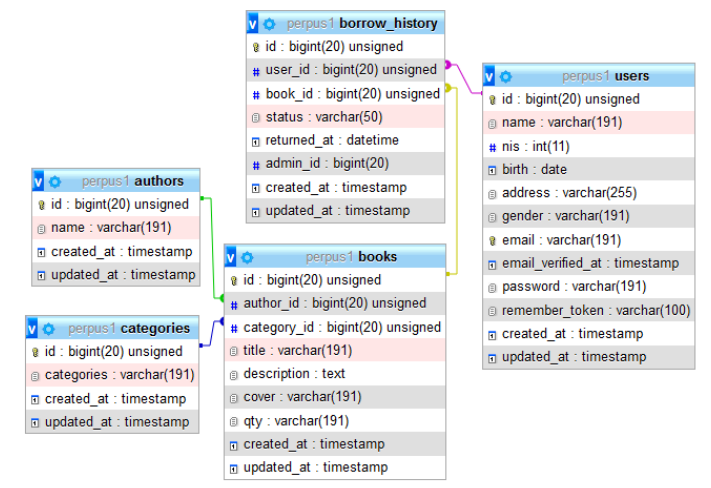

Gambar 7. Rancangan Relasi Tabel (Sumber : Penulis 2021)

\section{Tampilan Layar}

a. Halaman Landing Page

Halaman landing page

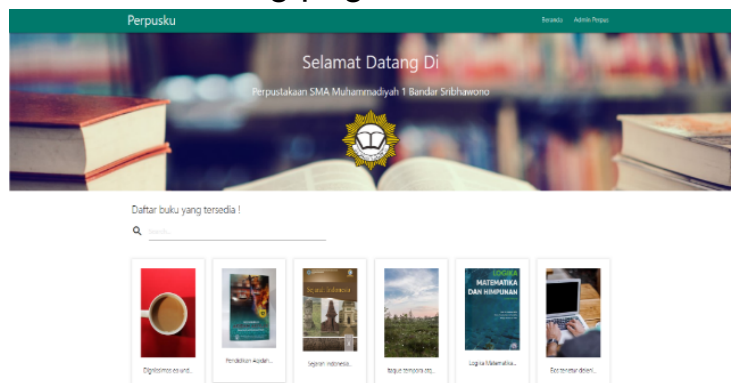

Gambar 8 Tampilan landing page

b. Halaman Informasi

Halaman Informasi

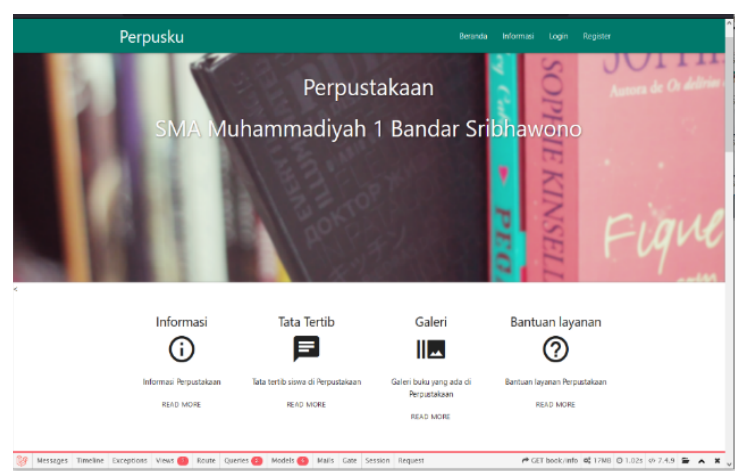

Gambar 9. Tampilan Halaman Informasi

c. Halaman Login

Halaman Login 


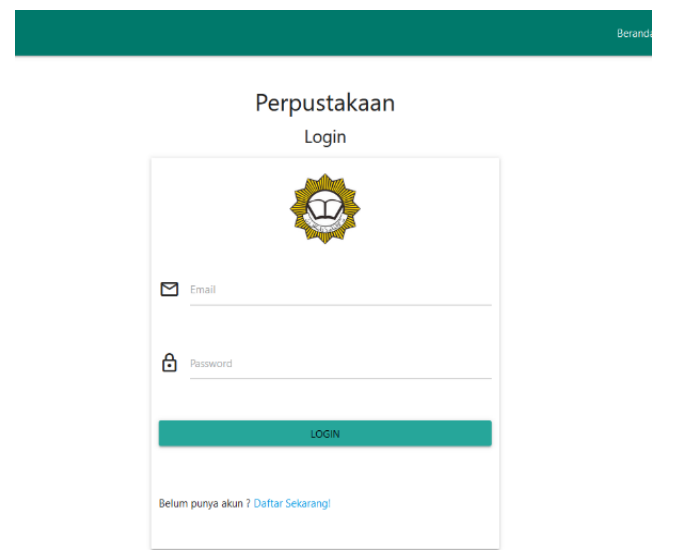

Gambar 10. Tampilan Halaman Login

d. Halaman Register.

Halaman register

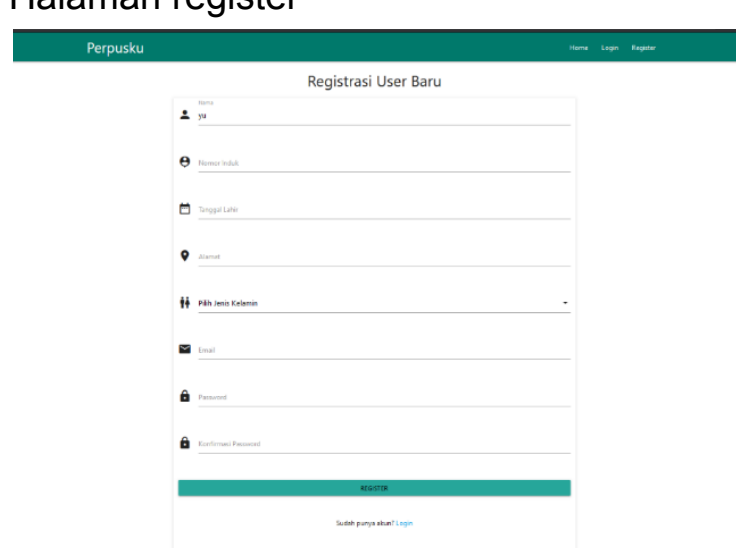

Gambar 11. Tampilan Halaman Login

e. Halaman Dashboard Siswa Tampilan Halaman Dashboard Siswa
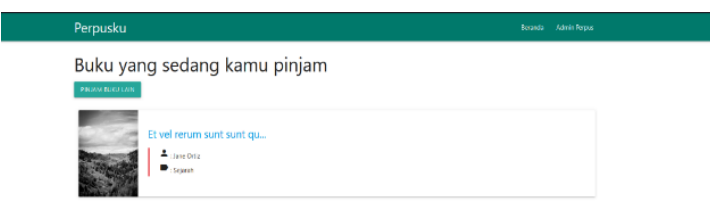

Gambar 12. Tampilan Halaman Dashboard

f. Halaman Detail Buku

Tampilan Halaman Detail Buku

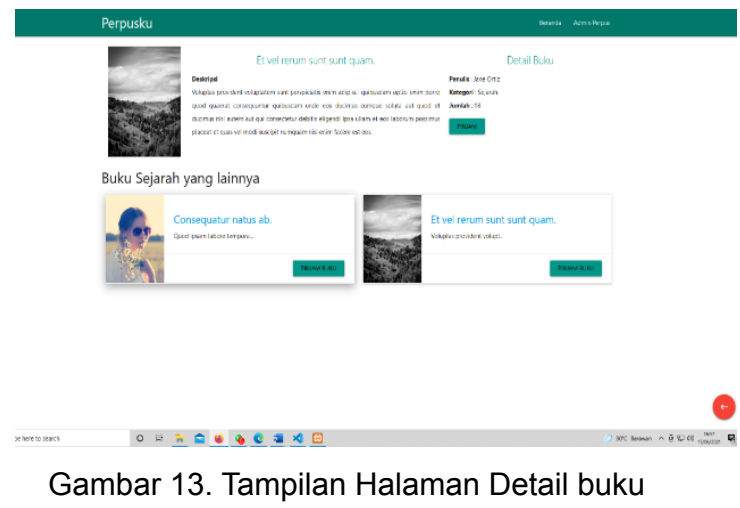

g. Halaman Admin

Tampilan Halaman Dashboard Admin

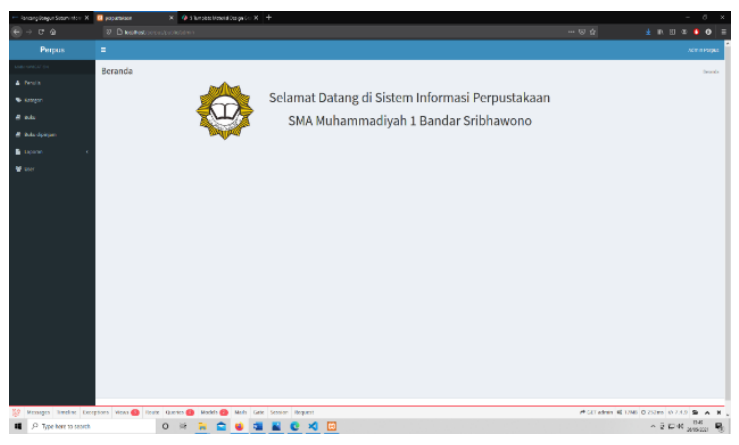

Gambar 14. Tampilan Halaman Dashboard Admin

h. Halaman Tampil data

Tampilan Halaman Tampil data penulis

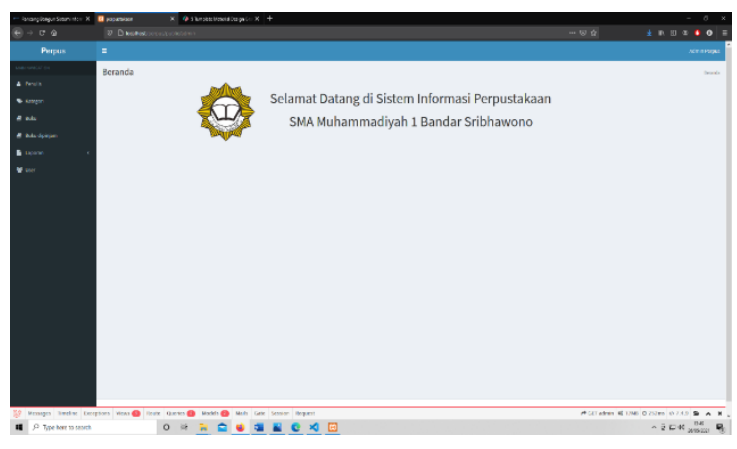

Gambar 15. Tampilan Data

- i. Halaman Tambah data

Tampilan Halaman Tambah data buku 


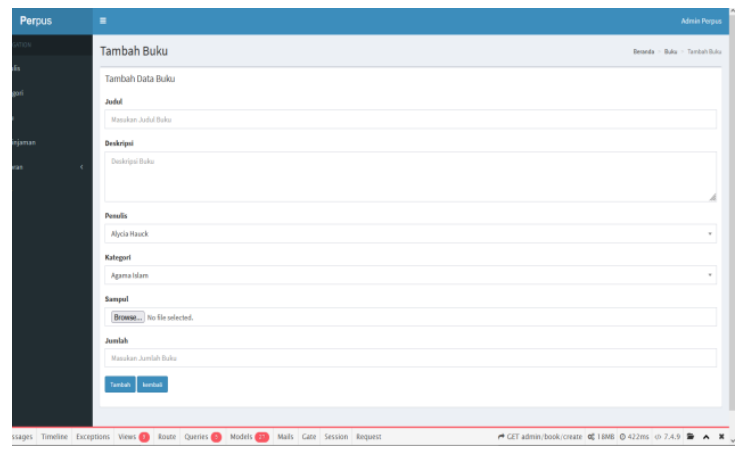

Gambar 16. Tampilan Data tambah data

j. Halaman Ubah data

Tampilan Halaman Ubah data Buku

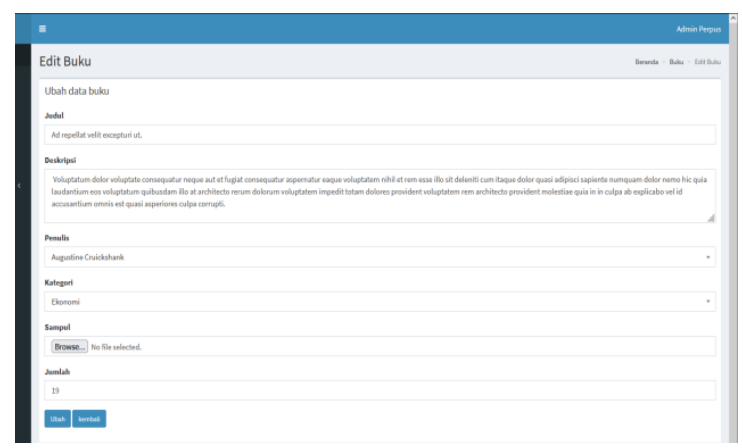

Gambar 17. Tampilan Ubah data buku

k. Halaman cari data

Tampilan Halaman cari data Buku

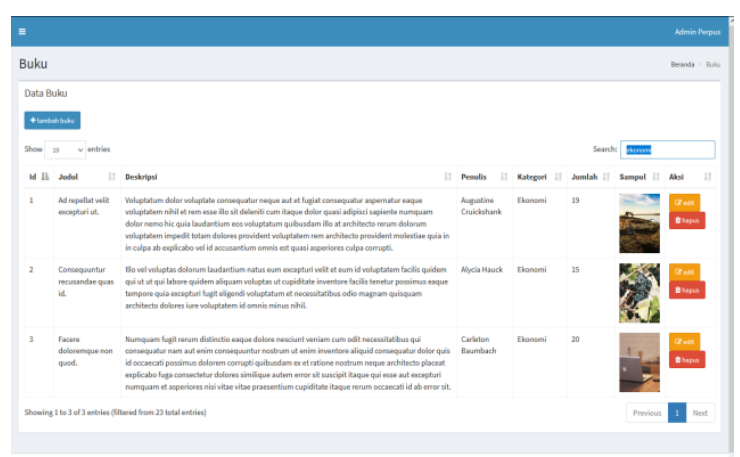

Gambar 18. Tampilan Data Cari buku

I. Halaman Peminjaman

Tampilan Halaman Peminjaman

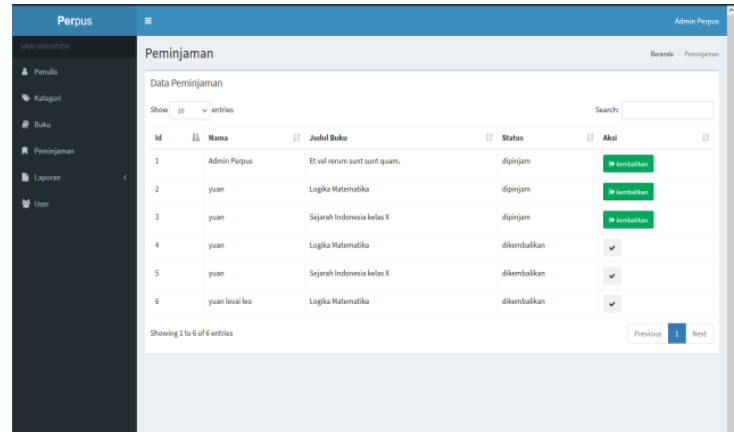

Gambar 19. Tampilan Data Cari buku

m. Halaman Laporan

\section{Tampilan Halaman Laporan}

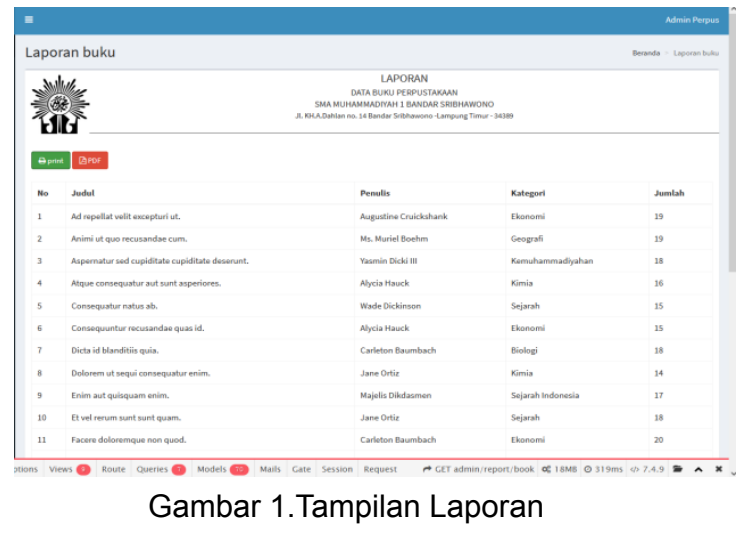

\section{KESIMPULAN}

Setelah melakukan penelitian pada SMA Muhammadiyah Bandar Sribhawono, penulis menarik kesimpulan bahwa tujuan dari penelitian ini tercapai dimana telah dihasilkannya sebuah Sistem informasi sesuai tujuan penelitian merancang sistem informasi peminjaman dan pengembalian buku perpustakaan pada SMA Muhammadiyah 1 Bandar Sribhawono. dari hasil penelitian tersebut, maka dapat disimpulkan bahwa :

a. Sistem informasi peminjaman dan pengembalian buku perpustakaan berbasis web di SMA Muhammadiyah 1 Bandar Sribhawono Dalam pengembangannya menggunakan framework Laravel. 
b. Proses pengembangan software menggunakan model RAD (Rapid Application Development) yang terdiri dari tiga tahap, (1) Perencanaan (2) Desain Workshop RAD, (3) Implementasi.

c. Sistem informasi ini memiliki beberapa fitur seperti pendaftaran anggota, pengelolaan data inventaris buku, peminjaman dan pengembalian buku, dan pembuatan laporan.

d. Sistem informasi yang dibangun dapat memberikan kemudahan bagi petugas perpustakaan dalam mengolah data perpustakaan

e. Sistem yang dibangun dapat mempermudah siswa dalam meminjam buku di perpustakaan.

\section{REFERENSI}

[1] Sugiyanto Ikhsan dan Gunardi, "Sistem Informasi Honorarium Berbasis Web Di Dinas Pemakaman Dan Pertamanan Kota Bandung," Co-Management J. IIm. Manaj. dan IImu Sos., vol. 1, no. No. 2, pp. 183-196, 2019, [Online]. Available: https://journal.ikopin.ac.id/index.php/comanagement/article/view/166/128.

[2] M. Destiningrum and Q. J. Adrian, "Sistem Informasi Penjadwalan Dokter Berbasis Web Dengan Menggunakan Framework Codeigniter (Studi Kasus: Rumah Sakit Yukum Medical Centre)," J. Tekno Info, vol. 11, no. 2 , p. $30, \quad 2017$, doi: 10.33365/jti.v11i2.24.

[3] N. S. Syahrul Mauluddin, "Sistem Informasi Persediaan Dan Penjualan Barang Berbasis Desktop Di D-Net House," Pros. Semin. Nas. Tek. Komput. dan Rekayasa, no. October, pp. III-12, 2017, [Online]. Available: https://repository.unikom.ac.id/id/eprint/ 54646.

A. Herliana and P. M. Rasyid,
"Sistem Informasi Monitoring Pengembangan Software Pada Tahap Development Berbasis Web," J. Inform., vol. Vol.III, no. 1, pp. 41-50, 2016.

[5] N. A. Rahmawati and A. C. Bachtiar, "Analisis dan perancangan sistem informasi perpustakaan sekolah berdasarkan kebutuhan sistem," Berk. IImu Perpust. dan Inf., vol. 14, no. 1, p. 76, 2018, doi: 10.22146/bip.28943.

[6] Erjon, D. Widi, and R. P. Ameliya, "Rancang Bangun Aplikasi Peminjaman Buku Untuk Meningkatkan Manajemen Pelayanan Perpustakaan Di Smp 1 Abung Tengah Lampung Utara," J. Manaj. Pendidik. Al Multazam JMPA, vol. 1, no. 2, pp. 38-47, 2019.

[7] A. Suryadi, "Rancang Bangun Sistem Pengelolaan Arsip Surat Berbasis Web Menggunakan Metode Waterfall (Studi Kasus: Kantor Desa Karangrau Banyumas)," J. Khatulistiwa Inform., vol. 7, no. 1, pp. 13-21, 2019, doi: 10.31294/jki.v7i1.36.

[8] A. Haryanta, A. Rochman, and A. Setyaningsih, "Perancangan Sistem Informasi Perencanaan Dan Pengendalian Bahan Baku Pada Home Industri," J. SISFOTEK Glob., vol. 7, no. 1, pp. 87-95, 2017, [Online]. Available:

https://journal.stmikglobal.ac.id/index.p hp/sisfotek/article/view/132.

[9] N. Aini and S. Wicaksono, "Pembangunan Sistem Informasi Perpustakaan Berbasis Web menggunakan Metode Rapid Application Development (RAD) (Studi pada: SMK Negeri 11 Malang)," J-Ptiik.Ub.Ac.Id, vol. 3, no. 9, p. 9, 2019, [Online]. Available: http://j-ptiik.ub.ac.id/index.php/j-ptiik/arti cle/download/6236/2996. 